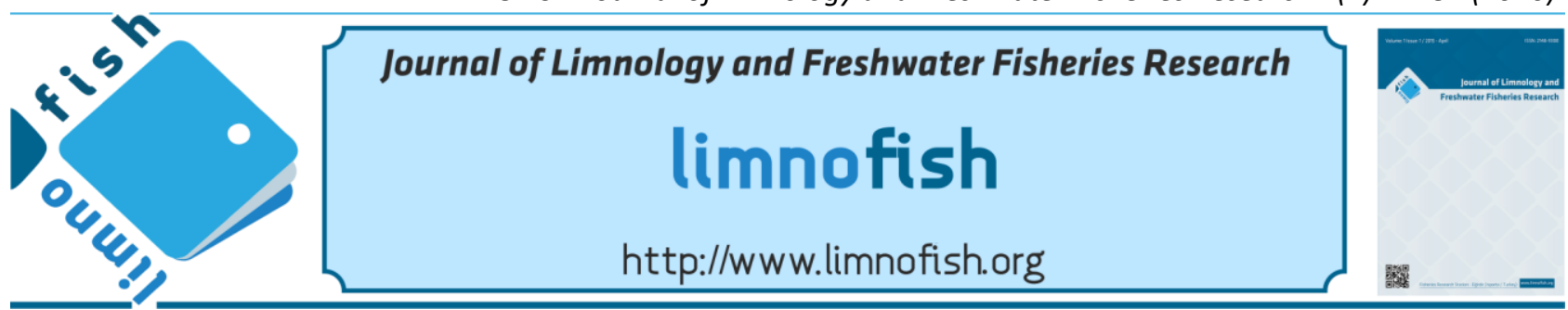

\title{
Is Zeolite a Detoxificant: Modelling of Ferrous Chloride/Zeolite Application of Aquatic Organisms on Rainbow Trout (Oncorhynchus mykiss) to Determine Its Effects on Oxidative Stress
}

\author{
Arzu UÇAR, Gonca ALAK*, Muhammed ATAMANALP, Esat Mahmut KOCAMAN \\ Ataturk University, Faculty of Fisheries, 25240 Erzurum-Turkey
}

\section{A B STRACT}

Populations of native fish and aquatic ecosystems have been negatively affected by the contamination of ground and surface waters as a result of various activities. Due to the ferrous chloride $\left(\mathrm{FeCl}_{2}\right)$, which is used as the reducing agent for the organic synthesis reactions in the contamination of water column and sediment, iron salts may be very toxic for some aquatic organism. In order to minimize these effects, natural products such as zeolite have been widely used recently. For this reason, rainbow trout (Oncorhynchus mykiss) were exposed to $\mathrm{FeCl}_{2}$ and/or zeolite for 28 days and their oxidative stress responses were investigated. At the end of the treatment period, oxidative stress responses were determined with antioxidant enzyme activities in the samples taken from liver and kidneys. CAT, SOD, GPx and MDA values for kidney and liver tissues were found statistically important between control and treatment groups $(\mathrm{p}<0.05)$. In this study, zeolite application provided lower values in terms of enzyme activities, and the protective effect of zeolite for aquatic organism was supported by biochemical parameters.

Keywords: Zeolite, fish, oxidative stress, enzyme, detoxificant

\section{ARTICLE INFO}

$\begin{array}{ll}\text { RESEARCH ARTICLE } \\ \text { Received } & : 15.03 .2016 \\ \text { Revised } & : 14.06 .2016 \\ \text { Accepted } & : 16.06 .2016 \\ \text { Published } & : 20.08 .2016\end{array}$

DOI: 10.17216/LimnoFish-5000181736

\section{* CORRESPONDING AUTHOR}

galak@atauni.edu.tr

Tel : +904422317038

Fax: +904422317065

Sucul Organizmalarda Demir Klorür/ Zeolit Uygulamasının Oksidatif Stres Üzerine Etkisinin Belirlenmesi İçin Gökkuşağı Alabalığında (Oncorhynchus mykiss) Detoksifikan Modellemesi

Öz: Çeşitli aktiviteler sonucunda yer altı ve yer üstü sularının kirlenmesi ile yerli balık popülasyonları ve sucul ekosistemler olumsuz etkilenmektedir. Su kolonu ve sedimentte meydana gelen kirlilikte organik sentez reaksiyonlarının indirgenme maddesi olarak kullanılan demir klorür $\left(\mathrm{FeCl}_{2}\right)$ sonucunda demir tuzları bazı akuatik canlılar için toksik olabilmektedir. Bu etkileri minimize etmek adına özellikle son yıllarda zeolit gibi doğal ürünlerin kullanımı yaygınlaşmaktadır. Bu amaçla çalışmamızda, gökkuşağı alabalıkları (Oncorhynchus mykiss) 28 gün boyunca $\mathrm{FeCl}_{2}$ ve/veya zeolite maruz bırakılarak oksidadif stres cevapları araştırılmışıır. Deneme süresi sonunda karaciğer ve böbreklerden alınan örneklerde oksidatif stres cevapları antioksidan enzim aktiviteleri ile belirlenmiștir. Kontrol ve muamele gruplarında böbrek ve karaciğer dokuları için CAT, SOD, GPx ve MDA değerleri istatistiki olarak önemli bulunmuştur $(\mathrm{p}<0,05)$. Bu çalışmada, enzim aktiviteleri açısından zeolit içeren gruplar daha düşük değerler vermiş ve zeolitin akuatik canlılar için koruyucu etkisi biyokimyasal parametrelerle desteklenmiştir.

Anahtar kelimeler: Zeolit, balık, oksidatif stres, enzim, detoksifikant

How to Cite

Uçar A, Alak G, Atamanalp M, Kocaman EM. 2016. Is Zeolite a detoxificant: modelling of ferrous chloride/zeolite application of aquatic organisms on rainbow trout (Oncorhynchus mykiss) to determine its effects on oxidative stress. LimnoFish. 2(2):77-81. doi: 10.17216/LimnoFish-5000181736

\section{Introduction}

Fish are generally used as bio-indicators for the determination of the conditions and changes of the aquatic environment. Thus, the degree and the type of the responses that fish give to these changes in the ecosystem at different levels should be known (Fabacher and Little 2000; Adams 2002). Studies on the metabolic and enzymatic activities of aquatic organisms are substantial and essential in terms of the determination of the ecological effects of the contaminants in fresh water and marine environment. Particularly enzymes, as physiological and biochemical indicators, are used for the determination of the health condition of aquatic organisms before seriously affected by these contaminants (Almeida et al. 2009; Alak et al. 2011). 
Factors such as detergents, some organic materials, industrial wastes, petroleum and derivatives, artificial agricultural fertilizers, radioactivity, pesticides, inorganic salts, artificial organic chemical materials, heavy metals and waste heat in aquatic ecosystems are important contaminants that accumulate and disturbing the ecological balance in aquatic ecosystems ( $\mathrm{Hu} 2000$ ). Living organisms are provided with antioxidant defence system (ADS) in order to be protected from the detrimental effects of these toxic compounds. Antioxidant enzymes are key components induced by oxidative stress (Alak et al. 2011; Uçar et al. 2012). The presence of an atmosphere rich in oxygen has ensured the development of an endogenous antioxidant system against reactive oxygen species (ROS) and reactive nitrogen species (RNS). The decrease in the products of this $\mathrm{O}_{2}$ metabolism controls the enzymatic (SOD), (CAT) and (GSH-Px) cellular defence mechanisms (Uçar et al. 2012). These enzymes are vital for the cellular balance; their induces are caused by the reaction to the contaminants and antioxidant enzyme activities and lipid peroxidation are substantial for the investigation of cellular damage in toxicological studies (Alak et al. 2011; Dogliotti et al. 2012).

Ferrous molecule $\left(\mathrm{Fe}^{+2}\right)$, which has important roles in the living organism system, is found in different forms in the nature and mostly taken in through drinking water and food. It is known that the increase of $\mathrm{Fe}$ molecule in the body increases the radical production and also has a role in the increment of the hydroxyl radical, which is effective particularly in the lipid peroxidation of $\mathrm{FeCl}_{2}$, and hydroxyl- like radicals. Interest for the natural products has increased in order to prevent the negative effects of materials such as iron and aluminium in the regulation of water quality parameters, and studies on the utilization of alternative products have intensified. Among these products zeolites, which are found in large reserves in nature, are widely used for the elimination of heavy materials in water thanks to their sodium aluminoslicade and clay minerals, their ability of ion exchange and detraction of cations and their low cost (Nicula et al. 2010; Dayangaç et al. 2011; Çoğun and Şahin 2012).

Despite numerous studies on the usage of natural or synthetic products in the contamination, there is no study focusing on the materials of both group and on the determination of the oxidative stress response in the organism of aquatic system. The present study was modelled on rainbow trout, a locomotive species of culture fishing, in an attempt to scrutinise the topic in question and to constitute a reference for the future studies.

\section{Materials and Methods}

Fish maintenance and experimental design

Fish were obtained from Ataturk University, Faculty of Fisheries, Inland Water Fish Application and Research Center and the study was conducted at Fisheries Application and Research Center's Toxicology Experiment Unit during 28 days. Fiberglas tanks of $1 \mathrm{~m}$ diameter and $1 \mathrm{~m}$ depth with inclined tube drainage system and 40 rainbow trout (Oncorhynchus mykiss) of two years old and $165 \pm 25$ $\mathrm{g}$ weight were utilized in the research.

Filtered water was distributed to the tanks as no less than $0.5 \mathrm{l} / \mathrm{min}$ for $\mathrm{kg}$ fish. During the research, water temperature was measured as $11.5 \pm 2.5^{\circ} \mathrm{C}, \mathrm{pH}$ was 7.4 and dissolved oxygen was $9.1 \mathrm{mg} / \mathrm{l}$. Fish were randomly distributed to 8 tanks with 5 fish per tank. Two of the tanks were determined as control and the other 6 tanks were the treatment groups. $\mathrm{FeCl}_{2}$ application dose LC5096 value was utilised and $1 / 2(0.002 \mathrm{mg} / \mathrm{lt})$ of this dose was applied to tanks (Billard and Roubaud 1985). Stock solutions of $\mathrm{FeCl}_{2}$, obtained from a company (Sigma), were prepared with ultra distilled water and were applied to the tanks with determined water volume according to the experiment procedure of renewed environment in the concentration to form this dose once every 12 hours. Zeolite was determined as $1 \mathrm{~g} / \mathrm{lt}$ covering the tank floor (Nicula et al. 2010). Control and treatment groups were designed as $\left(\mathrm{FeCl}_{2}(0.002 \mathrm{mg} / \mathrm{lt})(\mathrm{A})\right.$, $\mathrm{FeCl}_{2}+$ zeolite $(0.002 \mathrm{mg} / \mathrm{lt}+1 \mathrm{gr} / \mathrm{lt})$ (B), zeolite (1 gr/lt) (C) and control (without $\mathrm{FeCl}_{2}$ and/or zeolite (D). Enzyme activities of catalase (CAT), superoxide dismutase (SOD) and glutathione peroxidase (GPx) and also malondialdehyde (MDA) levels were determined in liver and kidney tissues for all groups.

\section{Enzyme Analyses}

At the end of the trial, treatment and control group fish were euthanized by cervical section, their liver and kidney tissues were taken and freezed in liquid nitrogen, and then tissue samples (liver and kidney) were waited at $-86^{\circ} \mathrm{C}$. These tissue samples were waited in ice for 5-15 $\mathrm{min}$ at room temperature to thaw, afterwards, weighted on a precision scale between the range of 0.5-1 g and completely washed in $0.9 \% \mathrm{NaCl}$ solution. $\mathrm{KH}_{2} \mathrm{PO}_{4}$ buffer solution of three times weight of the sample was added on the tissue samples splintered into small pieces. Samples were homogenised and centrifuged at $13000 \mathrm{rpm}$ for an hour at $4{ }^{\circ} \mathrm{C}$. Supernatants were taken and their enzyme activities were measured (Alak et al. 2013).

Superoxide dismutase (SOD) activity was measured by the method of Sun et al. (1998). The reaction mixture contained phosphate buffer $(\mathrm{pH}$ 6.5), nitro-blue tetrazolium (NBT) and enzyme fraction. The mixture was incubated for $20 \mathrm{~min}$ at 
room temperature and then $\mathrm{CuCl}_{2}$ was added for stop reaction and measured spectrophotometric at $560 \mathrm{~nm}$. One enzyme unit was defined as SOD activity that inhibits $50 \%$ of NBT reduction. Catalase (CAT) catalyses the degradation of $\mathrm{H}_{2} \mathrm{O}_{2}$. Its speed was spectrophotometrically measured by utilizing $\mathrm{H}_{2} \mathrm{O}_{2}$ 's feature of absorbing the light at $240 \mathrm{~nm}$ (Aebi 1984). Glutathione peroxidase (GPx) catalyses the oxidation of reduced glutathione (GSH) by hydrogen peroxide to oxidised glutathione (GSSG). Hydrogen peroxide is degraded to GSH in t-butyl hydroperoxides environment by means of GSSG formed by GPx, glutathione reductase (GR) and NADPH. GPx activity was measured by reading the absorbance difference at $340 \mathrm{~nm}$ during the oxidation of NADPH to $\mathrm{NADP}^{+}$(Beutler 1975). Malondialdehyde seconder product is formed as a result of malondialdehyde (MDA) lipid peroxidation. The measurement is based upon the absorbance measurement of the pink complex at $532 \mathrm{~nm}$, formed as a result of the incubation of MDA with thiobarbituric acid (TBA) at $95{ }^{\circ} \mathrm{C}$. According to Bradford (1976), protein levels of each sample were determined spectrophotometrically at $595 \mathrm{~nm}$ wavelength were recorded by determining the bovine serum albumin (BSA) as the standard (Alak et al. 2013).

\section{Statistical Analyses}

The obtained data were expressed as mean \pm SEM. Statistical analysis of data was done using Duncan test and analyzed using SPSS version 10.0 software. A value of $p<0.05$ was considered statistically significant.

\section{Results}

Heavy metals generally adhere to the functional groups of proteins such as imidazole, sulfhydryl, carboxyl, amino and peptide groups. In the enzymemetal toxicity, toxic metal displaces a beneficial metal in the active area of the enzyme and becomes effective by binding to the inactive area of the metal (Çoğun and Şahin 2012). Liver, placed at an important place between the general circulatory system and digestive tract, helps the foodstuffs to be properly metabolised and is provided with a group of mechanism that disposes potential harmful substances and detoxifies them. This organ also includes highly specific and selective transport mechanisms for necessary foodstuffs, and these foodstuffs not only provide the necessary energy but also supply physiologically important substances for the systemic necessities of the organism (Wepener et al. 2001). The effect of $\mathrm{FeCl}_{2}$ and zeolite applications on the fish antioxidant enzyme activities is given in Table 1. It was determined that there were statistically important differences $(p<0.05)$ between de treatment and control groups in terms of CAT and SOD enzyme activities. Differences between the groups were found to be not important at GPx and MDA levels.

It was reported that kidneys are important organs that helps the disposal of metals in fish, and branchia and liver are other important organs in this process (Çoğun and Şahin 2012). In this study conducted with rainbow trout, groups of single zeolite and its combination with $\mathrm{FeCl}_{2}$ for kidney tissue showed the lowest values in all research parameters (Table 2) and inter-group differences were found statistically important $(\mathrm{p}<0.05)$. The decrease observed in the $\mathrm{FeCl}_{2}+$ zeolite group is thought to be caused by the repression of $\mathrm{FeCl}_{2}$ levels in water by zeolites (Nicula et al. 2010). Concerning the decreases determined in the enzyme activities and MDA levels of kidney tissue, it is thought that metal binding proteins have a part in the increase of reactive oxygen species (ROS) formed by interaction with $\mathrm{FeCl}_{2}$ despite the fact that they are synthesised in kidneys (Kaya 2005; Çoğun and Şahin 2012). Depending on this increment, decreases are seen in the SOD activity levels of kidney and liver tissues, and these decreases are determined to be important $(\mathrm{p}<0.05)$.

Table 1. The effects of different doses of $\mathrm{FeCl}_{2}$ and/or zeolit on enzyme activities and MDA levels in liver tissue of Oncorhynchus mykiss

\begin{tabular}{ccccc}
\hline & GPx & SOD & CAT & MDA \\
\hline A & $0.01 \pm 0.00^{\mathrm{a}}$ & $0.14 \pm 0.04^{\mathrm{c}}$ & $46.78 \pm 5.25^{\mathrm{a}}$ & $0.45 \pm 0.00^{\mathrm{a}}$ \\
B & $0.01 \pm 0.00^{\mathrm{a}}$ & $0.63 \pm 0.15^{\mathrm{ab}}$ & $20.03 \pm 4.65^{\mathrm{b}}$ & $0.14 \pm 0.00^{\mathrm{a}}$ \\
$\mathrm{C}$ & $0.01 \pm 0.00^{\mathrm{a}}$ & $0.78 \pm 0.07^{\mathrm{a}}$ & $31.36 \pm 1.59^{\mathrm{c}}$ & $0.19 \pm 0.09^{\mathrm{a}}$ \\
$\mathrm{D}$ & $0.01 \pm 0.00^{\mathrm{a}}$ & $0.42 \pm 0.11^{\mathrm{bc}}$ & $17.12 \pm 0.82^{\mathrm{c}}$ & $0.32 \pm 0.02^{\mathrm{a}}$
\end{tabular}

(A:0.002 mg/lt FeCl 2 , B:0.002 mg/lt FeCl $2+1 \mathrm{gr} / \mathrm{lt}$ zeolite, C:1 gr/lt zeolite D:Control (without $\mathrm{FeCl}_{2}$ and/or zeolite)).All data points are the average of $\mathrm{n}=10 \pm \mathrm{SD}$, Different superscript letters indicate statistically significant differences $(\mathrm{P}<0.05)$ GPx CAT and SOD EU mgprotein ${ }^{-1}$, MDA value $\mathrm{nmol} / \mathrm{ml}$ 
Table 2. The effects of different doses of $\mathrm{FeCl}_{2}$ and/or zeolit on enzyme activities and MDA levels in kidney tissue of Oncorhynchus mykiss

\begin{tabular}{ccccc}
\hline & GPx & SOD & CAT & MDA \\
\hline A & $0.02 \pm 0.00^{\mathrm{a}}$ & $0.73 \pm 0.03^{\mathrm{ab}}$ & $48.80 \pm 14.00^{\mathrm{b}}$ & $0.47 \pm 0.18^{\mathrm{a}}$ \\
B & $0.01 \pm 0.0^{\mathrm{b}}$ & $0.06 \pm 0.01^{\mathrm{c}}$ & $9.37 \pm 2.25^{\mathrm{c}}$ & $0.26 \pm 0.06^{\mathrm{ab}}$ \\
$\mathrm{C}$ & $0.01 \pm 0.0^{\mathrm{b}}$ & $0.39 \pm 0.1^{\mathrm{bc}}$ & $8.16 \pm 1.57^{\mathrm{c}}$ & $0.08 \pm 0.00^{\mathrm{b}}$ \\
$\mathrm{D}$ & $0.02 \pm 0.0^{\mathrm{a}}$ & $1.33 \pm 0.4^{\mathrm{a}}$ & $92.89 \pm 28.41^{\mathrm{a}}$ & $0.38 \pm 0.04^{\mathrm{a}}$
\end{tabular}

(A:0.002 mg/lt FeCl, B:0.002 mg/lt FeCl ${ }_{2}+1$ gr/lt zeolite, C:1 gr/lt zeolite D:Control (without $\mathrm{FeCl}_{2}$ and/or zeolite)).All data points are the average of $\mathrm{n}=10 \pm \mathrm{SD}$, Different superscript letters indicate statistically significant differences $(\mathrm{P}<0.05)$ GPx CAT and SOD EU mgprotein-1, MDA value $\mathrm{nmol} / \mathrm{ml}$

\section{Discussion}

Heavy metals accumulate in liver the most, because it is detoxification organ. In the present study, groups with zeolite showed a decrease in MDA and CAT enzyme activities compared to control and groups with $\mathrm{FeCl}_{2}$, and this was attributed to the ion exchange ability of zeolite. Similarly, in a study on the protective effect of zeolite, it was reported that there were increases in the levels of some parameters (protein, RNA and glycogen level) and zeolite showed a protective effect (Balasubramanian and Kumar 2013).

Single and combination applications of zeolite and $\mathrm{FeCl}_{2}$ caused increases in the CAT specific activities of fish liver, and higher values were recorded compared to the control (Table 1). Statistical analyses showed that inter-group differences were important $(\mathrm{p}<0.05)$.

Superoxide dismutase and catalase are the first and most important step in the defence against toxicity. It is known that enzymatic antioxidants taking part in the detoxification of $\mathrm{H}_{2} \mathrm{O}_{2}$, such as CAT, are higher in blood, bone marrow, mucous membranes, kidney and liver compared to other tissues, and show higher activity. Similar to our results, CAT activity was recorded to increase depending on the applications in the liver of tilapia (Orechromis niloticus) by Peixoto et al. (2006) and green snakehead (Channa punctatus) by Sayeed et al. (2003). In this study, high CAT enzyme activity in the liver and kidney tissues arises from the presence of this enzyme in kidney and liver (Peixoto et al. 2006) indicated that catalase enzyme activity is exposed to both inhibition and induction against some contaminants, and that they are not among the effective biomarkers in toxicology studies.

Antioxidant enzyme activities, glutathione redox level and lipid peroxidation are generally preferred biomarkers in toxicology studies (Oruç et al. 2004). Particularly the intracellular changes at GSH level are accepted as important indicators of oxidative stress caused by contaminants in fish (Zhang et al. 2005; Çınkıloğlu 2007). Increases at GSH level under contaminant effect are explained by the regulations and activations by enzymes taking part in GSH synthesis to replace the GSH level (Çınkıloğlu 2007). In this study, it is thought that decreases in the GPx in kidney and liver tissues under $\mathrm{FeCl}_{2}$ compared to control are caused by $\mathrm{O}_{2}$ increase (Matkovics et al. 1987; Y1lmaz 2010).

MDA levels in the tissue groups with $\mathrm{FeCl}_{2}$ show remarkable increases. In addition, it is thought that increases observed in the CAT enzyme activities of these groups can compensate the increase in lipid peroxidation (Kaya 2005). Since, it is known that $\mathrm{FeCl}_{2}$ is effective in the increase of hydroxy and hydroxyl-like radicals effective in lipid peroxidation (Dayangaç et al. 2011). In zeolite groups, MDA level decreased compared to the control and groups with $\mathrm{FeCl}_{2}$ alone, and this showed that zeolite protected these tissues against lipid peroxidation (Wu et al. 2013).

As a result of the study, regular follow up of the contamination in natural water environments has been deemed necessary based on the obtained data. Moreover, effect mechanisms of the alternative natural products used and their effects on aquatic organisms should be determined by biochemical and molecular based studies, thus generate a database. Based on the study results, zeolite can be said to show a protective effect. However, although there are studies in the literature that we can compare our research results, there is no study about the effect of zeolite on the antioxidant systems of fish. This study, in which single and combinational usage of two products used in water purification $\left(\mathrm{FeCl}_{2}\right.$ and zeolite) constitutes a substantial reference for future studies.

\section{References}

Adams MS. 2002. Biological indicators of aquatic ecosystem stress. American Fisheries Society; Mayland, North Carolina.

Aebi H.1984. Catalase in vitro. In: Lester P, editor. Methods in enzymology. New York: Academic Press; 1984. 121-126 p. 
Alak G, Atamanalp M, Topal A, Arslan H, Oruç E, Altun S. 2013. Histopathological and biochemical effect of humic acid against cadmium toxicity in brown trout gills and muscle. Turk J Fish Aquat Sci. 13:315-320. doi: 10.4194/1303-2712-v13_2_13

Alak G, Sönmez AY, O Hisar. 2011. Effect of some pesticide on antioxidant enzyme activity of fish. J Agri Fac Ata Uni. 42(1):91-93.

Almeida JA, Barreto RE, Novelli ELB, Castro FJ, Moron SE. 2009. Oxidative stress biomarkers and aggressive behavior in fish exposed to aquatic cadmium contamination. Neotrop Ichthyol. 7(1):103-108. doi: 10.1590/S1679-62252009000100013

Balasubramanian J, Kumar A. 2013. Effect of sodium arsenite on liver function related enzymes of cat fish Heteropneustes fossilis and its chelation by zeolite. Ecotox Environ Cont. 8(2):53-58. doi: 10.5132/eec.2013.02.008

Beutler E. 1975. Red cell metabolism, a manual of biochemical methods. 2nd ed. New York: Grune and Starton, $160 \mathrm{p}$.

Billard R, Roubaud P. 1985. The effect of metals and cyanide on fertilization in rainbow trout (Salmo gairdneri). Water Res. 19(2):209-214. doi:10.1016/0043-1354(85)90202-7

Bradford MM. 1976. A rapid and sensitive method for the quantitation of microgram quantities of protein utilizing the principle of proteindye binding. Anal Biochem. 72(1-2):248-254. doi:10.1016/0003-2697(76)90527-3

Çınkıloğlu E. 2007. Effects of fenthion in the brain of Cyprinus carpio on antioxidant defence system, lipid peroxidation and acetylcholınesterase enzyme activities by the modulation of n-acetylcysteine. [Master thesis]. Çukurova University. 83p. [in Turkish]

Çoğun HY, Şahin M. 2012. The effect of zeolite on reduction of lead toxicity in nil tilapia (Oreochromis niloticus Linnaeus, 1758). Kafkas Univ Vet Fak. 18(1):135-140. doi:10.9775/kvfd.2011.5170

Dayangaç A, Özkaya A, Bahşi M. Çiftçi B, Akyıldız G, Ö Y1lmaz. 2011. Linalool protects some unsaturated fatty acids in the rat liver and kidney against to $\mathrm{FeCl}_{2}$-induced damage. Düzce Üni Sağ Bil Ens Derg. 1(1):12-17.

Dogliotti G, Malavazos AE, Giacometti S, Solimene U, Fanelli M, Corsi1 MM, Dozio E. 2012. Natural zeolites chabazite/phillipsite/analcime increase blood levels of antioxidant enzymes. J Clin Biochem Nutr. 50(3):195-198. doi: 10.3164/jcbn.11-63

Fabacher DL, Little EE. 2000. Diversity of fish, early observations and descriptions, fish in experimentation. In: Ostrander GK, editor. The handbook of experimental animals. London: Academic Press. $678 \mathrm{p}$.

Hu H. 2000. Exposure to metals. Occup Environ Med. 27(4):983-996.
Kaya E. 2005.The effects of chlorpyrifos and deltamethrin on antioxidant enzyme activities and the malondialdehyde level in blood and brain tissues]. [Master thesis]. Süleyman Demirel University. 69 p. [in Turkish]

Matkovics B, Witas H, Gabrielak T, L Szabo. 1987. Paraquat as an agent affecting antioxidant enzymes of common carp erythrocytes. Comp Biochem Phys C. 87(1):217-219. doi:10.1016/0742-8413(87)90206-4

Nicula M, Bănăţean-Dunea I, Gergen I, Hărmănescu M, Simiz E, Pătruică S, Polen T, Marcu A, Lunca M, S Szucs. 2010. Effect of natural zeolite on reducing tissue bioaccumulation and cadmium antagonism related to some mineral micro- and macronutrients in Prussian carp (Carassius gibelio). AACL Bioflux. 3(3):171-179.

Oruç EÖ, Sevgiler Y, N Uner. 2004. Tissue-specific oxidative stress responses in fish exposed to 2,4-D and azinphosmethyl. Comp Biochem Phys C. 137:43-51.

Peixoto F, Alves-Fernandes D, Santos D, A Fontaínhasfernandes. 2006. Toxicological effects of oxyfluorfen on oxidative stress enzymes in tilapia Oreochromis niloticus. Pestic Biochem Phys. 85(2):91-96. doi:10.1016/j.pestbp.2005.10.007

Sayeed I, Parvez S, Pandey S, Bin-Hafeez B, Haque R, S Raisuddin. 2003. Oxidative stress biomarkers of exposure to deltamethrin in freshwater fish, Channa punctatus Bloch. Ecotox Environ Safe. 56:295-301. doi:10.1016/S0147-6513(03)00009-5

Sun Y, Oberley LW, Y Li. 1988. A simple method for clinical assay of superoxide dismutase. Clin Chem. 34(3):497-500.

Uçar A, Ali Al-Hamdani AH, Alak G, Atamanalp M, Topal A, Fakıoğlu Ö, Arslan H, Parlak V, T Şensurat. 2012. Effects of carboxin on superoxide dismutase enzyme activite in rainbow trout (Oncorhynchus mykiss). BİBAD Res J Biol Sci. 5(2):083-085.

Wepener V, Vuren JHJ, Du Preez HH. 2001. Uptake and distribution of a copper, iron and zinc mixture in gill, liver and plasma of a freshwater teleost, Tilapia sparrmanii. Water SA. 27(1):99-108.

Wu Y, Wu, Q, Zhou, Y., Ahmad, H., Wang T. 2013. Effects of clinoptilolite on growth performance and antioxidant status in broilers. Biol Trace Elem Res. 155(2):228-235. doi: $10.1007 / \mathrm{s} 12011-013-9777-6$

Yilmaz M. 2010. The effects of some pesticides on acetylcholinesterase, antioxidant enzyme activities and the malondialdehyde level in tissues of rats. [PhD thesis]. Çukurova University. 69 p. [in Turkish]

Zhang JF, Liub H, Sun YY, Wang XR, Wu JC, Xue YQ. 2005. Responses of the antioxidant defenses of the goldfish Carassius auratus, exposed to 2,4dichlorophenol. Environ Toxicol Phar. 19(1):185-190. doi:10.1016/j.etap.2004.07.001 